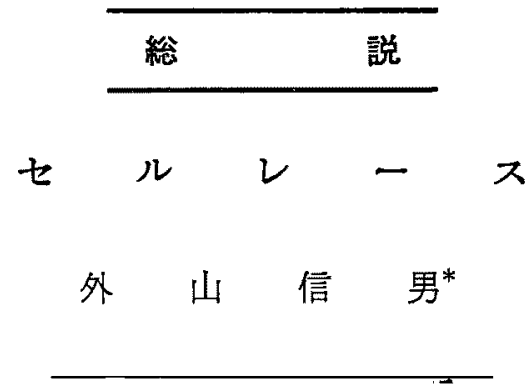

セルレース (cellulase) は 10 年前までは学者にとっ て厄介な問題であった。当時の微生物や醉素標品で注せ ルロースの分解が遅い上に， cellulase に実用性が注と んどないと思われていたから敬遠気味であった。ところ が微生物培養法の急速な進歩と分析技術の躍進に加元 て，分解が容易なため実験便利な水溶性セルロースの 出現などにより 1950 年代には cellulase の基礎的研究 が一応でき上った感がある。この研究は微生物による木 材，紙製品などの分解を防ぐために始妾ったのである が，逆儿これを皘極的棌利用しようとする機運が 1960 年に入ってから高まってきたのである。米国では数種の cellulase 製剂を市販するようになり，わが国でも時を 同じくして独特の cellulase 整削が誕生している。した がってセルレースに対する関心が学界, 業界に高亡り昨 年 11 月 25 日に第 1 回セルレース研究会が大阪大学工学 部，酰醉工学教室にて開催され，照井堯造教授が会長と なられ，本年 6 月 23 日には第 2 回の研究会唯盛会裡に 開かれ，次回は11月4日という具合にあわただしく進 展しつつある。本研究会のスポンサー注明治製菓，味の 素, 武田薬品, 協和醴酤, 旭化成, 寿屋, 東洋紡縝, 日 清製粉，森永製菓，日本パルプなどで，もともと業界の 発案で研究会が作られたのである。ところが米国側でも cellulase の著名な研究者である米国陸 軍開発研究所の ELWYN T. REESE 博土の世話で本年 3 月 26 日に第 141 回 American Chemical Society の大会の 1 部門として cellulase 汇関するシンポジゥムがワシントンで開催さ れている。これにはカナダの cellulase の権威 D.R. WHITAKER 博士などが参加し，日本よりも教育大の西沢 一倰先生と著者が招待され，なかなかの盛況であった。本 シソポジウムは 1950 年代の各 cellulase 研究者の成果 を持ち㟢り，一応整理する意味むあって電要な内容が発 表された次第である。末踏の領域の研究でも10 年たてば 大体の見通しがつくものである。そこで各研究者は総説
を書いて後進の道しるべとする義務むあるし，自分の頭 を整理する必要もあるのでこの方面の総説ないし著書は

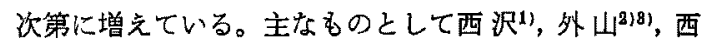
沢 $^{41}, \mathrm{KING}^{6)}$ および HALLIWELL ${ }^{11}$ のが挙げられる。こ の他 1959 年に Friday Harbor Symposia として D.L. RAY により編集された“Marine Boring and Fouling Organisms" 著名な cellulase 研究者達が投稿して いる。いずれも総説に類するもので著者の手許には Whitaker, ReESE, オーストラリヤの G. Youatt と M.A. JERMYN および京大食糧科学研 究所の門田教授の 各氏の別刷がきている。

著書としては $\mathrm{SIU}^{6}$, IMSCHENEZKI ${ }^{7}$ および GASCOIGNE ${ }^{8)}$ の3册がある。著者も1951 年より研究を始奶たのであ るが，この10年間で㦄用に必要な知識はすでに得られ たといってよい。研究を始めた頃は世界中に10指に充 た研究者がいたに過きないが，今日では全世界に研究 がひろがり，それぞれ特色のある成果が每月のように報 告されている。このとき垱り著者は最近の cellulase の研究の状況を概説し御参考化供することにした。1950 年代の成果については上記各総説を参照ありたいし，を たとくに引用交献を挙げておらねものは，すでに薪者が その総説で引用姵であることを了承されたい。

1. セルレースと CMC エース

Carboxymethyl-cellulose のソーダ塩を CMC と略 称する。こものの構造は次図に示され，glucose 1 単 位当り 1 コの置換基を持つ製品はェーテル化度 1.0 とい

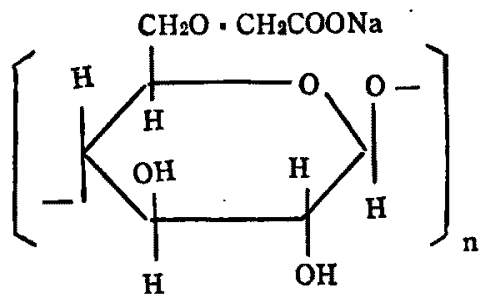

\footnotetext{
* 宮崎大学農学部応用徽生物学研究室（宮崎市船塚町）
} 
われる。エーテル化度 0.4 以上では水溶性となり市販 CMC たとえばセロゲンの重合度は 250〜450であり， エーテル化度は $0.65 \pm 0.05$ である9。CMC は簡単に分 解するので沢山のセルレース研究者に使用されたのであ るが，このために多くの人々が迷路に入り込えでしまっ たのが現状である。

各紛説に明らかなように CMC を分解するが沪紙や綿 をほとんど分解しない徽生物が沢山見い出されたのであ る。一方で CMC を分解主るから cellulose 分解性の微生 物だとか cellulase 標品だとされた例が多い。著者10は 洰紙電気泳動により Trichoderma の標品には沪紙をよ り上く分解する区分と CMC をよく分解する区分の 2 二 出存在することを報告した。いずれも cellulase として よいのであるがとくに後者を CMCase と仮称している。 外国でるや性り CMCase として特別に扱かわれるよう 棉なっている。また CMC 炭素源として微生物を分離 すると真のせルロース分解性菌は得られないと考允てい る向きもある。今日まで沪紙だけ分解して CMC を全 く分解しない醉素標品を得たものは 1 人もいないから， 単に特異性が異なるだけでみな cellulase として报って もよいとは考光られるが，一応区別した方が便利なこと は後記に示すごとくである。しからば自然界において CMCase に相当卞る酔素はいかなる役制をはたしてい るのであろうか。昔 WAKSMAN は Rhizopus と Trichoderma が協同すると，非常によくセルロースが分解文 れると報告したが，前者の CMCase が後者の cellulase により生じた分解産物をさらに分解除去してしまうから であろうか。この問題に KING がその総説で触れてい る。また CMCase の名す当然不適当でって水溶性の セルロースを分解する醉素に対して適当な名が必要であ る。

HALLIWELL ${ }^{11)}$ る天然セルロースより簡単なせルロース 性物質は $\beta-1,4$-polyglucosidase に上り分解されると 考え CMCase をその1例としている。天然せルロース 柱 $\beta$-1, 4-polyglucosidase であるか，一層複雑な構造 を持つためにこれを分解する cellulase は特別な醉素と 考えているが著者る替成である。かれによれば wood cellulose (沪紙もこれに入る) でも真の cellulase の研 笁には綿よりも不適当である。すなか台不純物を含むし その精製の際に受ける分解ははなはだしいから，微生物 または酵素により，綿よりもよく分解されるからであ る。かれ仕人工的に处理された基質の $10 \%$ 以下の水解 または重量挰失を与える程度の䤃素作用では真の celluJase が関与しておらず，酵素による効果は人工的処理
により生じた短かいセルロース鎖が分解したかららだと述 ベている。ついでに記すが，この $\beta-1,4$-polyglucosidase と $\beta$-glucosidase (cellobiose またはひろく一般 の $\beta$-glucoside を分解し transferase 作用も行なうと される）との間に cellodextrinase が当然考えられても よいようで事実知られている。STONE と KRISHNA MUR$\mathrm{TI}^{111}$ (1958) は Asp. niger のある抽出物加ら cellodextrinase と polyglucosidase の両区分を採り出し， 前者は cellobiose と cellopentaose によく作用し, 後 者は CMC と重合度 8 拈よび 5 の cellodextrin に作用 し，膨潤 cellulose に対してはごくわずかに作用するの を見い出している。YouaTI ${ }^{11)}$ (1958) む Stachybotrys atra から cellodextrinase を分雄 $し$, cellobiose から cellopentaose に至るむでの oligosaccharides と重合度 11 の cellodextrin を水解するのを認めたが CMCや cellulose 注水解しなかった。THOMAS ${ }^{11)}$ (1956) る同じ 菌で cellobiose, cotton および膨潤 cellulose に対して 不活性であるが cellotriose, cellotetraose および CMC を分解する抽出物を報じている。このように基質の鎖長 に対する特異性により，大体つぎのようにセルロース分 解酵素系を考えてもよいようである。もち諭境界の 1 部 が重なることもあるが。

Cellulase- $\beta-1,4$-Polyglucosidase-Cellodextrinase $-\beta$-Glucosidase

このように考えれば CMC を用いて "cellulase"を 研究することは一応意義があるが，CMC 自体にも問題 があることが指摘され始めている。たとえば CMC より ある中間産物が出てくるがこれを cellodextrins と間 遠う例がある。MYERS と NORTHCOTE ${ }^{11)}$ (1958) はカタ ッムリの消化醉素により生産された CMC の水解産物中 に glucose のほかに 3 㮔の化合物を見い出している。 汇紙電泳後 bromphenol blue の $1 \%$ 液で発色させれば わかることだが，その化合物が carboxymethyl sugar であって cellodextrin ではないとされている。さらに

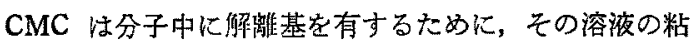
度が $\mathrm{pH}$ やイオン強度の影響を受けや寸く，粘度法の基

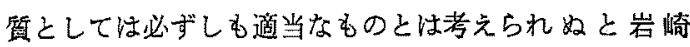
ら ${ }^{131}$ が述べている。DATTA ${ }^{181}$ らも CMC に対する Myrothecium cellulase の作用におよぼす尿素の影響を 研究した結果 CMC に対する活性が，醉素と基質の解離 していない carboxyl 基との間の水素結合により阻害さ れること，および尿素がその阻害を喴少することにより 活性が賦活されることが想像されると報じている。すな わち $\mathrm{CMC}$ 注基質として働くと同時酒素之複合物を作 
るのである。かかる相互作用は活性測定に影響し，測定 の条件に依存し醉素標品中の不純物による影響を受けや すいと述べている。

\section{2. セルレース活性の測定}

前記総説に明らかなように多数の測定法があるが、い ずれる人工的に相当に加工されたセルロース性基質を使 用している。例外として綿帆布を抗張力減少の試験に使 用している程度に過ぎない。これはかれらの微生物や醳 秦標品の“cellulase”が弱いからに汃ならない。学 問的にも工業的にも天然セルロースとほど遠い基質を使 ってはたして真相がつかめるであろうか。今日著者の研 究室ではガーゼを短時間に微細な繊維屑にしてしまう醉 菜的手段を発見し，普々として真の cellulase の分離を 目ざして進みつつある。とこでは著者考案の沪紙崩壊法 を紹介したい。沪紙ですら真の cellulase の測定に不適当 なのであるが CMCよりは透が真相に近いと信ずる。 そのゆえは Trichoderma の cellulase およびタカジフ スターゼを用いて生および蒸省した各種の植物性食品を 分解して比較したところ の組織が cellulase により非常に崩壊したのに，タカジ アスターゼによってはほとんど分解が見られなかった。 両者の酵素標品はともに CMC を分解するが，沪紙崖崩 壊できたのは Trichoderma の標品のみであった。年こ で食品分解でも沪紙を用いる活性測定法の方が一層よい 基準となると考えたのである。著者 ${ }^{15 !}$ は市販 cellulase の比較検定を目標として簢単迅速な測定法をつぎのごと く提案した。Monod 式恒温振とう機用の L 型管（ガラ 又製，内径 $18 \sim 19 \mathrm{~m} \mathrm{~m}$, 垂直部高さ $40 \sim 45 \mathrm{~m} \mathrm{~m}$, 水平 部長さ $143 \sim 148 \mathrm{~mm}$ ）に pH 4.0 に調節した酵素液 5 $\mathrm{ml}$ を入れ，東洋沪紙 No. 2 の $1 \times 1 \mathrm{~cm}$ の紙片 2 枚を

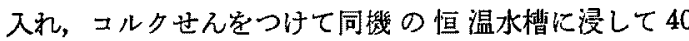
${ }^{\circ} \mathrm{C}$ で振とうし，2枚の沪紙が完全に崩濖して微細な䋐 維屑になるのに必要な時間を測定する。その㭙間 $x($ 分 $)$ と酵素液 $5 \mathrm{~m} l$ 中の酵䒺標品重量 $y(\mathrm{mg})$ を用い(150) $\boldsymbol{x}-\boldsymbol{y}) \times 10000$ で算位を算出している。通常酵素浱度を 1 \%にして測定している。ここで 150 というのは当時の Trichoderma 拏の風乾物の 5 倍量 $(\mathrm{v} / \mathrm{w})$ の水による抽 出液が示す崩壞所要時間である（現在では菌株の遙択と 培養法の進歩により 45〜60 分で崩墂している)。この方 法で測定すると米国製の Asp. niger の cellulase 裴绪 のほとえどは沪紙崩垻力が皆無であった。これらの製戍 は CMC の粘度低下やその䌅化力はあるのに, 国産 Trichoderma および同 Asp. niger の cellulase 製剂 の示す強力な沪紙崩唗力は認められないのである。
もち論沪紙崩壊に伴って生ずる糛を測定してもよいの であるが，実は共存する cellobiase の影響索考えねばな らない。cellulase 功強いから cellobiase 強いと住限 らず，Trichoderma の場合に性菌株と培養条件により cellulase が最強であるのに cellobiase がほとえどない 標品も作れるので，糖で測定しては判断を誤る場合があ る。Glucose と cellobiose の還元力は 2:1 と見られる からであるし，ときには transferase 作用む考虑に入れ ねばならぬがす知れぬ。との沪紙崩壊法は着色した酵素 液でも差しつかえないし，一時に多数の試料を短時間で 測定できる点汢大変便利であるが，一方機械的な影響が あるのでこの点索統一する必要がある。このため明治製 荣では Trichodermaより標準 cellulase 製郕(本法で5 00 単位）を製造している。これを使用すれば各研究室の データのハシラッキを非常に少なくし得る。

また同社と東洋沪紙の協力によりるっとも品質にムラ のない本法用の沪紙る製造されている。

\section{3. 七ルロース分解性糸状菌}

今日までにセルロース分解性微生物は数多く登場し， それぞれ重要な知見を与えたのであるが，学問的にもま たとくに工業的応用の見地よりはつきの 2 種類に落着い たように見える。培養が容易で生育が早く，強力な cellulase 製剂がたやすく得られる点で Trichoderma と Asp. nigar に敵するものはない。セルロース分解の 研究にあれほど貢献した真黒な系状菌 Myrothecium verrucaria む今日では寸っかり Trichoderma に席を僙 った感があり，国産の Trichoderma の cellulase 製 敖が海外の研究室で色々な研究に使われ始めている。 Trichoderma viride は土墡からきわめて容易に分離で きる淡緑〜濃緑色の総状菌叢生ずる紎菌である。通 常の系状菌用培地をべトリ皿に入れ，これに土を乘せる ¿ Mucor, Rhizopus, Penicillium 户 Aspergillus が最 初に生育してくるが, やがて Trichoderma が增光始め たいていの場合他のかびを制压して，どのペトリ且を Trichoderma の世界になること多くの人々は経験し ておられると思う。とくに Rhizopus の菌薪に Trichoderma の2〜3の菌㳥が晃られてから1〜2日もする と全くRhizopus 悄消えたうになり Trichodermaに なってしまう。むしろ T. viride は生物学的植物防涳 棛として使われる方が有名なくらいである。本菌が多数 の微生物学者に存在を認められ，そのセルロース分解性 が早くから知られていたにもかかわらずその実用面が一 向に開発されなかったのは真に興味がある。おそらく大 方の応用微生物学者は醇造に関係深い菌にの多注目して 
しまったのであろう。

しかるに本菌の cellulase は䤈造にとってもきわめて 有力な手段となりつつあるのは皮肉なことである。著者 蛨を炭素源としてこれに合成培地を加え，手で毎日軽 く振って本菌を培養すると綿が次第に微細な織維屑にな ることを知り，取扱った範囲の多数のかびでは全くこの ような現象が起らないととに興味を持台研究を始めたの である。今日でもこれに匹敵する糸状菌を知らない。と ころで本菌は今日では $T$. viride として統一されてし まった変った菌であるが，胞子の形や菌瞨の色や色素生 産などに相違のある菌株があり，また綿党用いた合成培 地で明暸に異なるものがあり，著者の長年の経験では少 なくとも2つのタイプに大別し得るようである。

しかしいずれのタイプでもフスマ整にすれば強力な cellulase を生産する。かつどの菌株でも数菌と同樣に 容易に製棃できるのむ強味である。つぎに T. viride に つぐセルロース分解菌は Asp. niger であ万う。しかし 後者は菌株によって cellulase に強弱がはなはだしく， 前記の米国の cellulase 製剂に沪紙崩壤力が全く認めら れぬという場合もあるのである。しかし著者の研究室で 選択したものは天然セルロース上にも生育し，培罜条件 によっては今日工業的に培養されている $T$. viride は 少し劣るがなお相当な沪紙崩壊力を示しこれも工業的 cellulase 生産に用いられている。

ただ Asp. niger は同時に cellulase のほかに色々な 醉素を副生しそのいすれれも活性が強いのが目的によ。 ては非常に有利である。たとえば食品分解では cellulase は劣っても(以前の Trichoderma よりは沪紙崩滾力が 大である) protopectinase p pectinase の強いAsp. niger の cellulase 製绪の方が有効な場合が多いし， $\mathrm{pH}$ 3.0でも cellulase がよく働くことも有利であるう。と く蚂内の条件に似ている $\mathrm{pH} 2.4,40^{\circ} \mathrm{C}, 30$ 分のご とき酸性加熱処理により T. viride $の$ cellulase 轅剂中

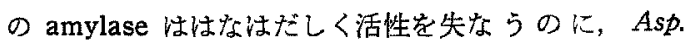
nigerのそれはほとんど影響を受けないから消化戍とし ては後者の製戍が望ましい。ただ後者の amylase や protease などが強力なので，食品加工の場合は過分解 を起こして本来の目的沿かぬことがある。食品加工で はときに細胞膜のみを分解して，有效成分をそのまま残 したいことがあるが，このために cellulase や hemicellulase のみを含む䤃素製削が必要となり，この目的 には T. viride でなければならぬようである。前述の ごとくガーセ゚すら簡単に分解できる強力な cellulase 裴 戍は Trichoderma によってのみ調彆できるようであ
る。

4. セルロース分解性とは

すでに読者はセルロース分解性とは何かについて概念 は作られたであろうが，今少しし細に檢討を加えておか。 权ばなら收ととがある。BASU ら ${ }^{16 !}$ 法適当な基質に育て ると今まではセルロース非分解性と見られた糸状菌が， 天然セルロースとまでは行かぬにしても比較的複雑なせ ルロースでる分解できる醉素を生産することを見い出 している。すなわち Jute (黄麻)，フルカリ処理 Jute, Juteより調留 した holocellulose, $\alpha$-cellulose, hemicellulose，および汇紙を用いて 124 㮔のが゙が cellulase. 生産のために試験されている。この cellulase は汾末沪 紙および膨潤てルロースを基質として測定されている。 このうち 15 種がどの基質で培䓹してる cellulase 生産 できず，48種唯沪紙上でそれを生産している。ところが大 部分のかびは色々な物質を含えでいるせルロース性基質 により cellulase を作るのが認められた。この最後のグ ループに通常セルロース非分解性とされているかびが沢 山含をれている。これに反して数種の有名なセルロース 分㑇性のかびが cellulase をほとえど作れなかったので ある。かかる不純セルロース性基質中の微量の栄養物と hemicellulose が醭素生産を刺激するとされている。す るとこのような有機的生育因子があれば，セルロースを 分解できるかび（一層ひるく分布する）があることにな， りなかには分離したときには cellulase をよく生産す るが，次第にその能力を失なうむのがあることになる （たとえば biotin が無いと汇紙上に亩たなくなる）。結 局せルロース分解性のかびに他の炭素源を与光ると，七 ルロースの節約作用が起こり cellulase を余り作らなく なるのであろうか。著者はセルロース分解性紎状菌にこ のような 2 つグルーブが存在すること牥あり得ると思

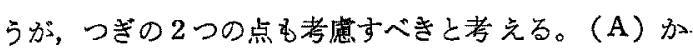
れらは天然せルロースを基質として cellulase を測定し ていない。（B）セルロース上にさかれに生育して，た とえば綿帆布の抗張力を激减させるような微生物のなか には細胞外にほとえどまたは全く cellulase を分䎵しな いものがある。

著者は今後セルロース分解性とは天然セルロースを可 溶性の物質にまで分解し得る性質と定義したい。BAsU らは $\beta$-1, 4-polyglucosidase を报っていると見なして

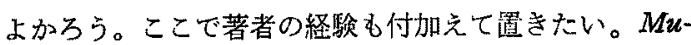
cor や Rhizopus のごとき湔以前よりルロース非分解 性と考元られまた Asp. oryzae は Grassmann らによ り cellulase を有するとされているが，これらをフスマ 
鷘にしてその抽出液を用いて汗紙崩壇法で則定して見る と T. viride や Asp. niger に蚂及ぶべくも無いが,一

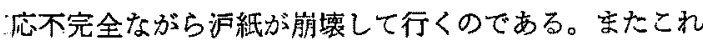
ら全ての菌は CMC を分解する。REESE の定義による cellulase $\mathrm{Cx}$ は主として CMC で測定されているが, かれは modified cellulose ( $C_{1}$ にり天然 cellulose が分解した結果生じた cellulose という意味むあるが， 人工的に処理して得た cellulose という意味も含まれる) を分解する醉素を指している。澎瀾セルロースも沪紙む modified cellulose に入れるべきである。すなわち汇紙 崩壊法では $\mathrm{Cx}$ を測定しているのである。また合成培地 を用いて綿上に色々のかびを育てると，著者の报った範 囲では Trichoderma のみがきわめてさかえに生育し， Asp.niger はある菌株のみがやっと生育し他のかびは

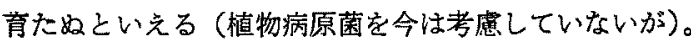
著者の経験でこれらの菌の各基質に対する分解力を表示 するとつぎのようになる。第 1 表は著者の研究室で使用 中の菌について数の場合や培善汇液の場合などを全て考 えてその平均的な活性を示したものである。Penicillium についてはその種類ははなはだ多いので一概にい光ない が，著者の経験およびこれまでの海外の諸研究より見 $\tau$, cellulase の工業的生産の見地からは余り希望方持 てないようである。ところで同じ Cxでも前述のごとく 沪紙と CMC との分解が平行しない例がある。すなわち 米国製 cellulase や Takadiastase は沪紙を崩壊しなか った。数抽出液と醅素製剂では cellulase に関して同一 菌種のむのでる活性に差があるようだが，この両基質の 分解性を、爻别した方がよいことは著者むさきに記したと ころである。飽くまで便宜的なすのであるが，REESEに ならって沪紙を分解する酻素を $\mathrm{C}_{2}$ とし， CMC に対す るそれ它 $\mathrm{C}_{8}$ として著者の研究室では报うことにしてい る。 $\mathrm{C}_{2}$ を沪紙䎲限らずフルカリによる膨潤セルロース などの不溶性で，かつ人工的処理を施したセルロース性 基質を分解する醉素とし，C8 8 を一般の水溶性せルロー ス誘導体を分解する酵素と見なして研究を進めている。

第 1 表 セルロース性基質に対するかびの分解力

\begin{tabular}{|c|c|c|c|}
\hline & 綿 & 沪䋊 & $\mathrm{CMC}$ \\
\hline Trichoderma viride & Htt & Hth & 世 \\
\hline Aspergillus niger & \pm & H & 册 \\
\hline Aspergillus oryzae & - & $H$ & $H$ \\
\hline Rhizopus sp. & $\overline{\mathrm{C}_{1}}$ & & $\#$ \\
\hline
\end{tabular}

5. セルレースの適応的生成

前記のぜとくセルロース分解性系状菌といっても2つ のグループに大別されるが，乙れから扱うかびは従来か らセルロース分解性之見なされたものである。また細菌 のセレレースは多くが構成的に生産される（著者総説を 参照されたい）ので省略する。cellulase の生産汇はセ ルロースを必要とするという観念は近年になって相当に 改为られている。他の䤃素でも同様らしいが，要するに 醭菜生産の誘起のためには誘起物質自身，またはその分 解生成物がその菌に代謝される基質である必要注少しを ないといわれる゙7》。また醉素の基質になるむの必らずし も誘起物質とならないのであって LEDERBERG ${ }^{17)}$ は $B$. coli を用いてネオラクトース（ $\beta$-D-ガラクトシドてル トロース) は $\beta$-galactosidase で分解されるが誘起作 用を持たないという。REESE と MANDELS 注不溶性の七 ルロースがどのようにして cellulase の誘起物質として 働くかを詳細化研究中である。かれら ${ }^{18}$ )は微量の cellulase が菌体内にすでに存在すると仮定して，セルロー スが存在すればこれにより水解され，生じた可溶性物筫 が細胞内に入りさらに多量の cellulase を誘起するとい う。ただかれらの “cellulase”は $\mathrm{Cx}$ であり CMCょ りの生成還元糖で測定しているのが賏念される。かれら は多くの微生物を試験したが, cellobiose はこれらのか びのすぐれた生育用基質で，またすみやが消費される が “cellulase” の生産ははなはだ低く, Trichoderma viride をこれで培養したとき生した“cellulase”の量 は，七ルロースでの生産量の5\%以下で，これはこの結 で急速に生育したために起こった阻害と失活によると思 われている。一方 Lactose 注がの生育基質としては 余り良好でなく、ゅっくり消費されるのに“cellulase” がはなはだよく生産される。またあるかびは cellobiose octaacetate 亿生育する。これ性不溶性物質である が， esteraseを作ることができるが゙により分解され， かかるが゙は cellobiose octaacetate 比生育するとき にしばしば cellobiose に生育したときより強い $\mathrm{Cx}$ を 作るし，ときには cellulose に生育したときよりる強い Cx 作るのである。一般に天然セルロースがもっとも cellulase 誘起し，セルロースを人工的に処理したも のを用いるとその生産量は下るし，可溶性セルロース誘 覚体で怯その生産量は低いのである。がれらはこれら誘 起物質の効率の順序をつぎのように示している。

Cellulose $\geqq$ Cellobiose octaacetate $>$ Lactose $>$ Cellobiose

$\mathrm{Cx}$ の生産に当って誘起物睤の瀑度も重要な影響をお 
よばすが，その消耗速度も重要である。 セルロースで培養すると cellobiose はゆっくり生産 されゆっくり消費される。广た Lactose む cellobiose octaacetateもゆっくり消費される。ゆ之にかれらは cellobiose の消費を緅慢にすることを試み,そして“cellulase" がよく生産されることを認めている。また $T$. viride では cellobiose は $\mathrm{Cx}$ の出現を阻害し, cellobiose が消賴されたのちにCx が出現するから，直接の 誘起物質は cellobiose 代謝の生産物か子知れない。か れらは oligosaccharase は transferase でもあると考 えているが，かれらが T. viride cellobiose に生育 させ，還元性が約 $50 \%$ 减少したとき培養沪液定 paper chromatography で調べると cellobiose のほかに一連 の炭水化物のスポットが現われ，このなかで RG0.4の 物質すなわち糖転移生産物は，若千のかびに与えると “cellulase”劣誘起し，一般に cellobiose, cellotriose をたは lactose より活性である。

また全て既知の誘起物犋は $\beta$-glycosidic 結合を含さ が，誘導しない物質もまたこの結合を含むことが判明し ている。ついでに REESE19) らは最近かびと醉母にり 生産される細胞外 sucrase の収量は，炭素源として sucrose monopalmitate 使用すると, それらの esteraseにより sucrose がゆっくり放出されるために非常 に増加されたことを報告している。ところがかれら゙20は さらに意外な“ “cellulase”誘起物質を見い出している。 そ机は試薬級の glucose が Trichoderma viride QM 6a にとって “cellulase”の強力な誘起物質である不純物 を含有することである。このものは corn starch の酸 による水解により生産された glucose 中にあって，酵 素による水解により生じた glucose 中にはほとんどな い。粗製の誘起物質は数種の色々の炭水化物を含有し， 量的には最初の glucose の約 $0.15 \%$ である。この物質 は洗浄した $T$. viride の菌系体で試験すると, $5 \mathrm{r} / \mathrm{m} l$ で “cellulase” の活発な誘起を行ない，少なくとも cellobiose の 200 倍だけ誘起した。かつ“cellulase” は非常に低い浱度 $(0.25 \gamma / \mathrm{m} l)$ で sophorose (2-O- $\beta$ D-glucopyranosyl-D-glucose) により誘起されること がわかっていて, glucose 中の不純物はこれらしいと推 測していたが最近それを確諗している。すなるちかれ ら泣試薬級 glucose 中に sophorose が0.0058\%に 含をれ，T. viride に対する “cellulase” の特翼的な 非常に強力な誘起物質で， cellobiose の実に2500倍す 活性であると報じている。かつ sophorose を還元した り glycoside にしたりすると誘起能が失われるという。
しかむ T. viride 泟常にゆっくりと培地から sophorose 吸收する。汃くて $T$. viride に対する $\mathrm{Cx}$ の既 知の誘起物質は少なくとも $\beta$-glucosyl group により $\mathrm{C}_{2}$ または $\mathrm{C}_{4}$ で置換された 1 つの glucose 単位を含む ことがわかったが、なぜ $\beta-1,2$ 結合がよく“cellulase” を誘起するのに， $\beta-1,3$ p $\beta-1,6$ 結合は完全に不活性 であるか朱解決である。またなぜ $T$. viride に対し て sophorose が特異的に動くのであるうか。われわれ

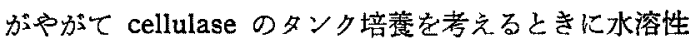
の強力な cellulase の誘起物質がほしいのであるが，こ れらの米陸軍開発研究所の成果に期待するものである。

\section{6. セルレースの多成分性}

分析技術の進歩により cellulase 標品が同様の活性を 有するいくつかの成分に分けられている。 cellulase に ついて WHITAKER の単一成分説と， REESE の多成分説 がそれぞれ提唱されていたが，この論争によりわれわれ はある1つの醉素系といえども真に複雑であり，しかも 環境の条件に微妙に動かされる事実を知り得たのであ る。今日では cellulase に限らず他の carbohydrases も殿粉ブロックを用いる zone 電泳により多成分性を示 している。酥素の結晶化は学問的研究には望ましいこと だが，とくに水解酵素については慎重な態度がとられね ばなるまい。著者の意見として（a）分析技術の進歩に 上り，以前は単一成分と見られたものがさらに分けられ る可能性がある。事実こんにち使われる長さ $1 \mathrm{~m}$ にる 及ぶ zone 電泳法に上机ば，大抵の水解酵素は多成分性 を示す。この方法ですら各ピークは接近してをり，各成 分または似た酵素の実際的分踓は不可能である。(b) 醉 素学検出するためには色々の基質を与えて試驗せねばな らない。あらゆる種類の基質を与えたのち始めて夾雑醉 素がないこと文証明できるが，これも実際的には不可能 である。cellulase にもxylan 分分解し得るるのと，xylanase とは全く別種のものもある。結晶 xylanase と 称しても CMCについての十分な試駼がなされていなけ れば不十分である。以上の 2 点から考えただけでも結晶 amylase や結晶 protease が採取されたことは奇跡と しか思われない。物理化学的手段がいかに精緻を誇って

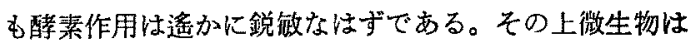
環境の条件や培養龄によりいつむ同じ䤏素を作るだろう か。培鉒初期に作る cellulase と後期に作るるれとは同 じものであろらか。近代的实睑手段で猴められた cellulase の研究は，他の水解醉素についても再検討を要す ること京している。 cellulase の多成分性については 前記総説に詳しいが，その後も，たとえば PRINS-VAN DE 
Meulen ら ${ }^{22)}$ は. $M$. verrucaria の “cellulase”の多 成分性を Amberlite IRC-50を用いて立証して，最近 西沢 ${ }^{29}$ \& Irpex lacteus (Polyporus tulipiferae) の cellulase 方殿粉 zone 電泳により 9 つの区分に分離さ れることを報告している。とくに注目すべきは MILLER ら ${ }^{24}$ の実験である。すなわら多成分性といっても基質特 異性の異なる cellulase 区分に分けられるのが普通であ るが， MULER らは必らずしもそうでないことを始めて 述べているからである。䢊わち Myrothecium verrucaria の cellulase を用い，殿粉 zone 電泳により9つ の成分に方方机，このうち5つの区分が cellopentaose と CMC に対する相対的醉素活性について，実際的炕 同一であることを見い出している。また残る3つは cellopentaose K対してやや高い比活性を持つようであ り，1 つは非常に低い比活性を示している。後者の4つ

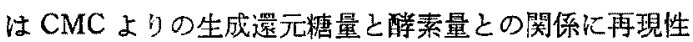
のある相異を示している。問題は前記5つの区分であ る。これは同じ cellulase が何かの影響を受けてわかれ るようになったのではあるまいか。これに関して MANDELS ら ${ }^{251} お よ ひ ゙ ~ W H I T A K E R R^{26)}$ の意見を述べておく。

(a) 多成分性 (Multiple nature) 活すてk沢山の carbohydrase について証明され，実際に全ての carbohydrase が多成分であり得ると思われ始めている。ふかる 多成分系のそれぞれの成分は MARKERT と M (1959）により提案された isozyme として考え得る。

(b) Steinberg \& Mihalyi のいj "sequential isomers”(配列の違う異性体)である醉素の形成すなお方 わずかな細かい部分が巽なるのみの醋素の形成が原因で ある。この場合にはフミノ酸の順序の相巽が正味の荷電 または形の本䓄的な差珙を与えるとともに，醉菜特異性 も定めるのであるう。(c) “Configurational isomers” すなわち主要な棈造に若干の相違のある酵素の形成も考 えられる。さらに全く買なったタイプの cellulase の形 成もあり得る。(d) 培地中に分泌された他の代謝産物と の女定な複合物の形成による。代謝産物も培菣条件によ り变化するが，こうした複合物の形成が cellulase の耐 熱珄や電泳の不均斦性の原因となる。が゙の培萄沪液中 には沢山の蛋白質の carrier が存在するが，電泳的に不 均質性を示す polysaccharide $に$ WhiTAKER はとくに注 意を㬇起している。(e) Cellulase が分泌されたのちで, 酵素活性に影㗽することなしに蛋白質の構造に影響す る㔻白分解またはその変性を受けることが原因である などと考竞られるのであるが，この汭を微生物の年 龄とか篓養状態とか，そのときの培表基質の状態とかが
複栋影な響を及ぼすであろうしまたこれが自然の姿で もあろう。後記のごとく cellulase のほかに色々な $\beta$ glucanase る登場し，zone 電泳でそれぞれの peak は 認められるが相互の完全分嶉は実際上不可能䎲近い。こ のような醅素の多成分性について，同じ作用を持つが分 子の形状が異なる (Multiple Molecular Forms) 醩素

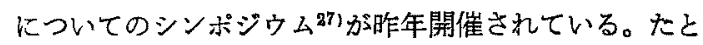
光ば多成分性の䤃素の存在が，それを作る生物に何ら かの利益を与光るのか，次山の形状のるのが個々に生産 されるのか，それともそれらの醇素の全てが 1 つ基本 的な形のものから導かれるのか,この多くの形状を持っ た醉素が，化学的にまた檴造的にいかに異なっているの かなどの問題が提起されている。この内容のなかにはた と光ば結晶性 ribonuclease が電泳の移動性が相互に異 なるように見劣る 5 成分にるかれることが示されてい る。

\section{7. セルレースの他の研究結果}

この 10 年間に確証されたセルロース分解や，セルレ 一スについての概念はつぎのとおりである。(a) 結晶領 域のセルロース㵊初に非水解的変化が起こったのちに 水解作用により分解される。最初比起こる变化について む色々の研究があるがなお不明である。(b) ある微生物 ではセルロース分解の後期の反応に，水解作用のほか に phosphorolysis が含まれる。(c) 自由に拡散する細 胞外 cellulase（かびに多い）之細胞の表面に結合され ている cellulase (細菌に認められている) とがある。 cellulase のあり方微生物の生活椂式之関係がありそ うで，たとえば䚈胃の細菌は瀻維と緊密に接触でき，周 囲の液体中へ cellulase 唯流れ去ら始ようにして攻慗を 集中できるのである28!。(d) Cellulase にはセルロース 鎖の内部の glucosyl 結合を分解する endocellulase と, その末端をた注準末端の結合のみを分解する exocellu

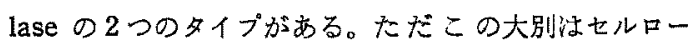
ス銧のみについていえるのであって，セルロースを 12 の塊りとして扱う場合には別な様式を考えねばなら外よ うである。SELBY291 は M. verrucaria の cellulase $に$ よる綿の分解を研究して，WHITAKER より提出されたい わゆる手当り次第のセルロース分解样式は十分に膨潤し たセルロース基質に対してのみ適用されるという。かれ は綿セルロースの分解が苛性ソーダによる前処理により 膨潤させられたときでさえも，手当り次第でもなく末端 からの分解のいずれでもない，別な機構に従うようだと 報じている。M. verrucaria の cellulase 占大きな分子 を有するから通動性が限られていて，とくにせルロース 
の構造内では，ほとんど移動性を持たないはずと考え， 比較的かずかの攻慗地点のそれぞれから隣接した glucose 残基を除くという。

またもしセルャースがリン酸で膨閏されるなら，醉素 の移動珄が増すので手当り次第の分解が観察される己報 じている。（e）他々な沘生物や異なる基質を用いて得ら れた結果から，セルロース分解に關する一般的理論を導 くことは危険である。YouATT ${ }^{80 J}$ むれを強調してい る。かれによれば Cellulomonas biazotea のセルロース 分解はその結晶度と共存 pentosan により影響される が，同じ条件で Sporocytophaga myxococcoides はどん なセルロース性基質でも同程度に分解するという。

\section{8. セルレースとその関連酵素}

Cellulase の関連酵素として hemicellulase (pentosanase, xylanase など) も考えられるが, 著者のいう それは $\beta$-glucanase である。すなるち $\beta-1,2, \beta-1,3-$ $\beta-1,4$ - (cellulase) および $\beta$-1,6-glucanase の 4 醭素 はとくに応用においては同様に注目されるべきである。 対照が量的に自然界にもっとも多いの怔 $\beta$-1,4-glucan (cellulose) であるからら cellulase がとくに注目される のであるが，食品その他の分解などに酵素を利用する場 合には，当然 $\beta$-結合の炭水化物にる関心を払わ标ば らぬことは第 2 表祖より明らかである。

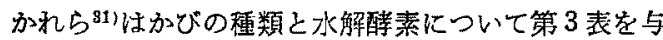
えている(代表例のみ)。さらに REESE Б年は Takamine 研究所の cellulase 慗靔 $(10000 \mathrm{U} / \mathrm{mg})$ 中の 他の $\beta$-glucanase についても第4 表の測定 傎を与えて いる。

REESE らはかびにおいてはこれらの $\beta$-glucanase の うち $\beta-1,2$-glucanase ${ }^{84)}$ は $\beta$-1, 4-glucanase $と$ 同 く適庁的に生産され， $\beta-1,3$-glucanase ${ }^{83)}$ 乙 $\beta-1,6-$ glucanase ${ }^{321}$ が構成的に生産されると哏じている。また

第2表 $\beta$-glycans の棈造と自然界での分布（STONE, 195831')

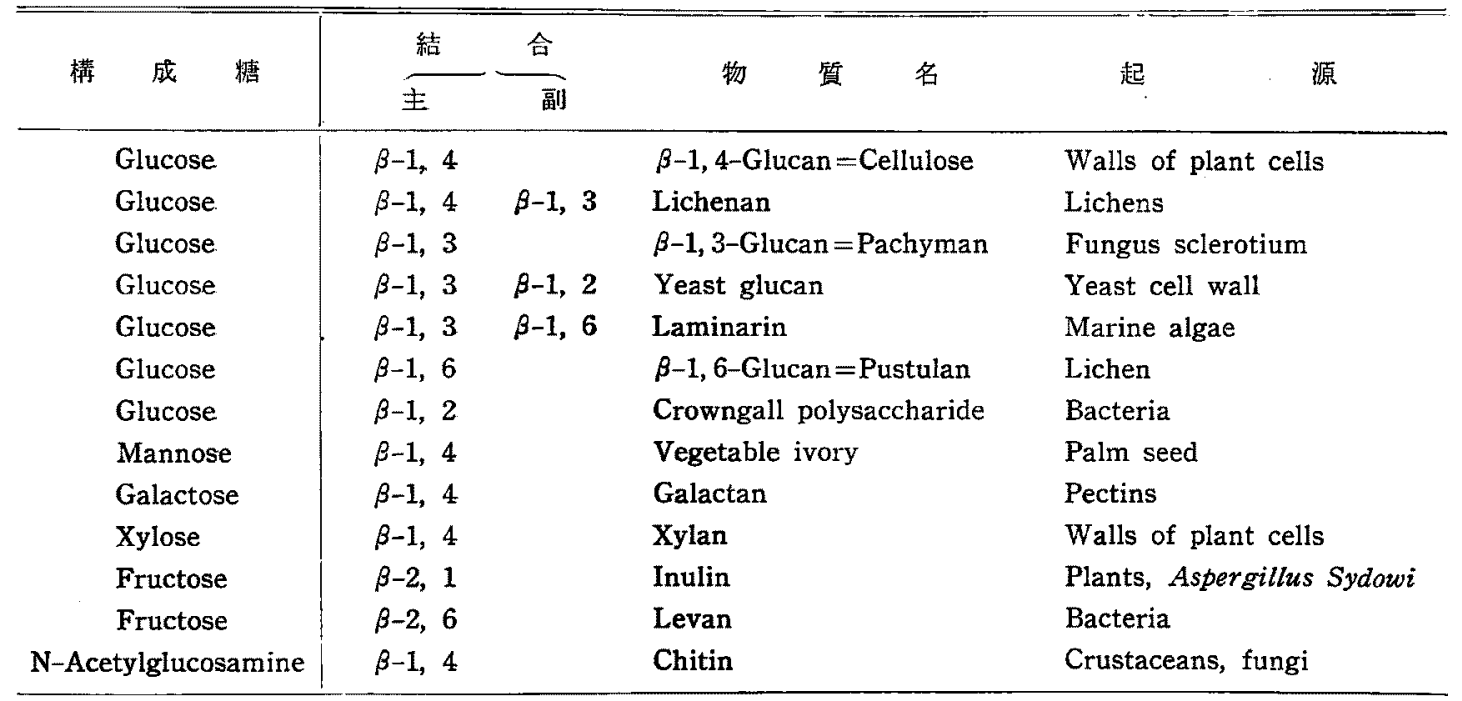

第 3 表 かびの水解硣素 ${ }^{811}$

\begin{tabular}{|c|c|c|c|c|c|c|c|c|}
\hline \multirow{2}{*}{ 加 } & \multicolumn{4}{|c|}{ Glucanase } & \multirow{2}{*}{$\overbrace{\text { Xylanase }}^{\text {他 }}$} & \multirow{2}{*}{ 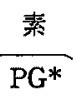 } & \multicolumn{2}{|c|}{ Glucosidases } \\
\hline & $\overline{\beta-1,4-}$ & $\beta-1,3-$ & $\alpha-1,4-$ & $\alpha-1,6-$ & & & $\beta-$ & $\alpha-$ \\
\hline Trichoderma viride & 9.0 & 0.7 & 0.5 & 0.0 & 0.6 & 0.06 & 0.2 & 0.1 \\
\hline Aspergillus luchuensis & 0.2 & 2.0 & 20.0 & 0.04 & 0.06 & 0.6 & 2.1 & 8.0 \\
\hline Myrothecium verrucaria & 0.8 & 0.2 & 0.0 & 0.0 & 0.0 & 0.0 & 0.03 & 0.0 \\
\hline Rhizopus arrhizus & 0.1 & 6.4 & 0.5 & 0.2 & 0.0 & 0.4 & 0.0 & 0.1 \\
\hline
\end{tabular}

注: * Polygalacturonase

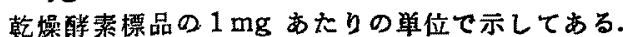


第 4 表 市販 cellulase 製削中の $\beta$-glucanase ${ }^{52)}$

\begin{tabular}{c|ccccc}
\hline \hline & \multicolumn{3}{|c}{ Glucanase $(\mathrm{U} / \mathrm{mg})$} & $\begin{array}{c}\text { Cello- } \\
\text { biase } \\
(\mathrm{U} / \mathrm{mg})\end{array}$ \\
\hline $\begin{array}{c}\text { Cellulase } \\
\text { Miles }\end{array}$ & 2.0 & 4.3 & 0.2 & 10.0 & 10.0 \\
\hline
\end{tabular}

それぞれの $\beta$-glucanase をよく生産するかびも選定さ れている。将来はそれぞれの $\beta$-glucanase を特異的に 含有する酥素製戍がこれらのかびから調製されて，それ らを適宜組合せて，たとえば食品加工などに応用される であろう。セルレース研究会の目的の1つはこれらの $\beta$-glucanase の開発という点にあるのである。

9. 七ルレースとその関連酵素の応用

すでにわが国においても Trichoderma viride や Asp. niger より cellulase 製削が明台智菓, 近戴ヤクルト,上 田化学工業および長瀬産業により隼造され，国内流もと より海外にも送られて，目下学界や業界により試験中で あるが，すでに国内では多数の応用に関する特許が申請 されている現状であり，海外でも真洒を発揮しつつあっ て学問的研究に採用されたのみか, 食品, 飼料などへの 疬用が色々と試みられつつある。国内の応用開発の状况 は改めて別にまとめることにして，ここには現在までの 海外でのそれを記す。REESE ら注色々な polysaccharide の構造を調查したり，植物よりある物質を分離する のに酵素を使うことを考えている。後者の場合，酸やア ルカリでは分解が強過ぎたり，広籍囲に分解されるので 都合が悪いことがある。它た細胞学的研究のために, 植物 の細胞壁を消化するのにカタッムリの cytase 標品が使 われている35!。かつカタッムリの消化管の抽出物中の強
W lipase 活性む，細胞壁中の lipoprotein 構造 の分解 に役立つから重要であるとされている。REESE ら 䤃素は大きな蛋白分子だから固体中に容易に拡散しない のが欠点であり，固体学粉砕すればよいのだが，これに より遊離すべき成分安破壊するか子知几ないと考元，軽 く粉势してさらに，容易に可溶性の成分を化学的に抽出 したのち醰素を作用させることが望ましいとしている。 ただしかれる述べているごとく新鮮で水気の多い組織は cellulase に上りたやすく分解される。かれらの報告で とくに興味があるのは不用な醉素を除く色々な手段，す なわち微生物の選规，培養条件および精製法であるが， これらはとくに分析用醉素削索作る上に大いに参考とな るであろう。第 5 表は REESE ら ある。この他に色々の結合を有する polysaccharides か ら2糖類などを調幣する方法, polysaccharides と oligosaccharides の同定法（とくに $\alpha$-または $\beta$-結合の） にもかれらは触れている。要するに醳素はおだやかな条 件で水解ができるし，中間産物を蓄積できるし，何より むその特異性が利用できる点に最大の長所があるから， 応用を食品に限っても色ふな加工が可能となろう。なお $\beta$-glucanase は糸状菌よりのものに限らず他の起源よ りのものむ注目すべきである。たとえば MoscatelLI $ら^{86}$ はデソマークの Novo 社の細菌 amylase の濃縮 物，すなわ方 Bacillus subtilis よりの市販酵素郕が，

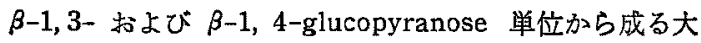
麦の $\beta$-glucan を分解する醅素を含むことを報じてい る。米国西部産大麦の飼料佂值を $B$. subtilis が改善する ことが知られて来たので，かれらはその原因と予想され る本醉素の精製および雛を用いる飼育試験を試みつつあ

第 5 表 混合物からある化合物の分離と精製31)

\begin{tabular}{|c|c|c|c|c|c|c|}
\hline \multirow{2}{*}{$\begin{array}{l}\text { 希望する } \\
\text { 生痤物 }\end{array}$} & \multirow[b]{2}{*}{ 原 } & \multicolumn{4}{|c|}{ 除かれるべき物質 } & \multirow[b]{2}{*}{ 醉 素の 起 源 } \\
\hline & & 性 & 質 & $\begin{array}{l}\text { 酵菜作 } \\
\text { 前 }\end{array}$ & $\begin{array}{l}\text { 醏素作 } \\
\text { 角 後 }\end{array}$ & \\
\hline Xylan & Xylan，市販品 & \multicolumn{2}{|c|}{ Glucan } & $23 \%$ & $8 \%$ & Rhizopus arrhizus QM 1032 \\
\hline Chitin & $\begin{array}{l}\text { 水, } 2 \% \mathrm{KOH} \text { および alcohol での抽 } \\
\text { 出後の mushroom (=乾燥量の } 25 \% \text { ) }\end{array}$ & \multicolumn{2}{|c|}{ Glucan } & 63 & 25 & Trichoderma viride QM 6 a \\
\hline Lignin & $\begin{array}{l}\text { ボールミルで粉砝した針樅（PEW， } \\
\text { 1957） }\end{array}$ & \multicolumn{2}{|c|}{$\begin{array}{l}\text { セルロースを } \\
\text { ヘミセルロース }\end{array}$} & 70 & 12 & 䤑素 No. $19 *$ \\
\hline Lignin & 針棁，木片（PEW，1957） & \multicolumn{2}{|c|}{$\begin{array}{l}\text { セルロースと } \\
\text { ヘミセルロース }\end{array}$} & 70 & $6 \sim 14$ & 生育する brown-rot fungi \\
\hline $\begin{array}{l}\text { Pento- } \\
\text { san }\end{array}$ & “Squeegee” 殿粉 (Simpson, 1954) & \multicolumn{2}{|c|}{$\begin{array}{l}\text { 蛋白筫 } \\
\text { 层粉 }\end{array}$} & $\begin{array}{r}8 \\
50\end{array}$ & $\begin{array}{l}1 \\
0\end{array}$ & $\begin{array}{l}\text { Proteinase } \\
\text { Amylase }\end{array}$ \\
\hline 殿、粉 & 小麦粉（SIMPSON, 1955) & \multicolumn{2}{|c|}{ Pentosan } & & & Pentosanase \\
\hline Olive oil & Olives (PINEDA, 1954) & \multicolumn{2}{|c|}{ Pectins } & & & Pectinase \\
\hline
\end{tabular}

注: * Rohm and Haas Co. 製 


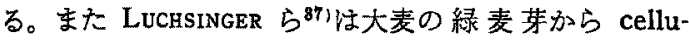
lase のほかに 2 種類の endo- $\beta$-glucanase を分離し， 後者が大麦 glucan 液の粘度をすみやかに減少するのを 認めている。との麦芽 $\beta$-glucanase の 1 つは焙焼によ り $90 \%$ が不活性化し，他はやや耐熱性で 50\% 活性が残 り，後者が壪造過程の糖化の際に重要な働きをすると報 ビている。PREECE ら ${ }^{88)}$ る大麦よりの酵素標品中に endo$\beta$-1, 3-glucanase, endo- $\beta$-1, 4-glucanase, exo- $\beta$-1, 4glucanase, Laminaribiase 枕よび一般的な $\beta$-glucosidase を含みをたからす麦よりの標品は endo- $\beta-1,4-$ glucanase に一層富えでいると推定している。かれら は麦酒醸造の一工程である麦芽糖化の際に cytase が必 要なことは昔から知られ，との醉素源としてからす麦が 用いられているが，これはからす麦から得られる endo$\beta$-glucanase は大麦から得られるものより遥かに強い からだと述べている。このほか REESE ら ${ }^{\text {899 }}$ は Mustard oil glucoside 水解する $\beta$-thioglucosidase Aspergillus sydowi QM $31 \mathrm{C}$ がよく作ることを報し，加工食 品の香気の改善のための醉素を高等植物の種子よりも経 闵的に製造できる見込みと述べている。このように cellulase を始めとする $\beta$-glucanase が食品加工の新し い手段となりつつあるが，一方自然界もよくしたもので cellulase の阻害物質が色々の植物に含まれるから注意 せねばならない。JERMYN と YouatT (1957)401 岋 Eucalyptus rostrata（ユーカリの木）中のそれを報じ， BELL ら $(1960)^{40}$ む米国南部産ブドウ (Vitis rotundifolia）の葉のなかのそれ，およびある植物による cellulase と pectinase の阻害を述べている。 MaNDELS ら ${ }^{40)}$ む葉，花，果実，小枝および木質部の抽出物について試 験し， cellulase の阻害物質が案外沢山あり，とくに北 米産のヤマモモ科の木や，若千の熱帯の木がこの物筫を 多量に含むととを認めている。かつ cellulase の 3 種の 天然の阻害物質により試験した他の carbohydrase が, ほとんぞ影響されぬことも見ているが，これらの cellulase や pectinase の阻害物 質は病菌に対する植物の防 ぎょに役立つものと考えられている。

$$
\text { 文献 }
$$

1）西沢一俊：蛋白質核酸醉素，2，12 (1957).

2）外山信男：䤀醉工学， 35，196 (1957)；３5, 247 (1957).

3）外山信男：酳醉工学，39, 511 (1961)；, 39, 627 (1961).

4）西沢一俊：せルレース研究会, 第 1 回シンボジウ 厶記録, 30 (1961).
5) KIng, K.W.: Virginia Polytech. Inst. Tech. Bulletin, 154 (1961).

6) Siv, R.G.H.: Microbial Decomposition of Cellulose, (Reinhold) (1951).

7) Imschenezki, A.A.: Mikrobiologie der Cellu lose, (Akademie-Verlag, Berlin) (1959).

8) Gascoigne, J.A. and Gascorgne M.M.: Biological Degradation of Cellulose (Butterworths) (1960).

9）小田英二：第一工業製薬社報，工業版，No. 243 , 3 (1957)

10) 外山・柴田：醴醉工学，39，262 (1961).

11) Halliwell, G.:Nutrition Abst. Rev., 29, 747 (1959).

12）岩崎・德安・船津：セルレース研究会，第 2 回シ ンポジウム、講演，(1962年 6 月).

13) Datta, P.K., Hanson, K.R. and Whitaker, D. R.: Biochem. Biophys. Acta., 50, 113(1961).

14) Toyama, N.: Mem. Fac. Agr. Univ. Miyazaki, 3, 71 (1962).

15) 北御門 - 外山：醄醭工学, 40, 85 (1962).

16) BAsu, S.N. and GHose, S.N.: Canadian J. Microbiol., 6, 265 (1960).

17) Kluyver, A.J. and van Nirl, C.B.: The Microbeś Contribution to Biology, 佐藤 - 丹 羽訳, (岩波書店) (1961).

18) Mandels, M. and ReEse, E.T.: J. Bacteriol., 79, 816 (1960).

19) Reese, E.T., Birzgalis, R. and Mandels, M.: Canadian J. Biochem. Physiol., 40, 273 (1962)

20) Mandels, M. and Reese, E.T.: Biochem. Biophys. Research Commun. 1, 338 (1959).

21) Mandels, M., ParRish, F.W. and Reese, E.T.: J. Bacterial., 83, 400 (1962).

22) Prins-van der Meulen, Schringa, G.J.: Natu$r e, 187,695$ (1960).

23) Nisizawa, K., Morimoto, I., Handa, N. and Hashimoto, Y.: Arch. Biochem. Biophys., 96, 152 (1962)

24) Miller, G.L. and Birzgalis, R.: Arch. Biochem. Biophys., 95, 19 (1961).

25) Mandels, M., Miller, G.L. and Slater, JR., R.W.: Arch. Biochem. Biophys., 93, 115(1961).

26) Whitaker, D.R.: Bull. Soc. Chim. Biol., 42, 1701, (1960).

27) Wróblewski, F.: Ann. N.Y. Acad. Sci., 94, 655 1030 (1961).

28) King, K.W.: J.Dairy Sci., 42, 1848 (1959).

29) Selby, K.: Biochem. J., 79, 562 (1961).

30) Youatt, G.: Australian J. Biol. Sci., 13, 188 (1960).

31) ReEse, E.T. and Mandels, M.: Appl. Microbiol., 7, 378 (1959).

32) Refse, E.T., Parrish, F.W. and Mandels, M.: 
Canadian J. Microbiol., 8, 327 (1962).

33) Reese, E.T. and Mandels, M.: Canadian $J$. Microbiol., 5, 173 (1959).

34) Reese, E.T., Parrish, F.W. and Mandels, M.: Canadian J. Microbiol., 7, 309 (1961).

35) Myers, F.L. and Northcote, D.H.: J. Exper. Biol., 35, 639 (1958).

36) Moscatelli, E.A., HaM, E.A. and Rickes, E.L.: J. Biol. Chem., 236, 2858 (1961).
37) Luchinger, W.W., Cochrame, D.G. and KneEN, E. : Cerzal Chem., 37, 525 (1960).

38) Preece, I.A. and GARg, N.K.: J. Inst. Brewing 67, 267 (1961).

39) Reese, E.T., Clapp, R.C. and Mandels, M.: Arch. Biochem. Biophys., 75, 228 (1958).

40) Mandels, M. Howlet, W., Reese, E.T.: Canadian J. Microbiol., 7, 957 (1961). 